\title{
Peran Teknologi Di Dalam Memoderasi Pengaruh Internal Networking Terhadap Kinerja Usaha Industri Kecil dan Menengah Pada Saat Pendemi Covid-19
}

Submitted Date:

24 Desember 2020

Accepted Date:

16 Februari 2021
Satria Tirtayasa

Universitas Muhammadiyah Sumatera Utara satriatirtayasa@umsu.ac.id

Hazmanan Khair

Universitas Muhammadiyah Sumatera Utara hazmanan@umsu.ac.id

Januri

Universitas Muhammadiyah Sumatera Utara januri@umsu.ac.id

\section{Suggested Citation:}

Nasution, M. I., Fahmi, M., Jufrizen, J., Muslih, M., \& Prayogi, M. A. (2020). The Quality of Small and Medium Enterprises Performance Using the Structural Equation Model-Part Least Square (SEM-PLS). Journal of Physics: Conference Series, 1477(2020), 1-7

Abstract:

The purpose of this research is to analyse the Effect of Technology as moderator variable Throught the relationship of Internal Networking (production and distribution) with SME's business performance. This study have been done in Covid19 Pendemy at Medan City. The unit of analysis of this research is Small Medium Enterprises (SMEs) company, where those company located in one area (cluster Small Medium Industry). The population of this research are 103 IKM and the sample are 103 SME (census). Data collection was used questionnaire, where the respondent are the owner of the SMEs company. The questionnaire response was high where 3 owner rejected to made responsed (rejeccted), thus this research have 100 questionnaires reponses. The analysis method was using Hierarchi Regression and process analysis was used SPPS. The results of the research showed that the production and distribution have positive and significant effect with SMEs performance. The effect of technology as moderator effect was found that negative and significant influence the relationship production and distribution with SMEs performance. Thus, the effect of technology as moderator variable in pendemic Covid-19 was not dominant, because of the SMEs compay faced decreased demand and indeed influence of Sales Margin.

Keywords: Internal Networking, SMEs performance, Technology

Abstrak:

Tujuan dari penelitian ini adalah untuk menganalisis Pengaruh Teknologi sebagai variabel moderator dalam hubungan Internal Networking (produksi dan distribusi) dengan kinerja Usaha IKM. Penelitian ini dilakukan di saat pandemic Covid-19 di Kota Medan. Unit analisis dalam penelitian ini adalah perusahaan Industri Kecil Menengah (IKM), dimana perusahaan tersebut berada dalam satu kawasan (cluster Small Medium Industry). Populasi dalam penelitian ini adalah 103 IKM dan sampelnya 103 IKM (sensus). Pengumpulan data menggunakan kuesioner, dimana responden adalah pemilik perusahaan IKM. Respon kuisioner tinggi dimana 3 pemilik menolak untuk membuat respon (ditolak), sehingga penelitian ini memiliki 100 respon kuisioner. Metode analisis menggunakan Regresi Hirarki dan analisis proses menggunakan SPPS. Hasil penelitian menunjukkan bahwa produksi dan distribusi berpengaruh positif dan signifikan terhadap kinerja IKM. Pengaruh teknologi sebagai pengaruh moderator ditemukan pengaruh negatif dan signifikan hubungan produksi dan distribusi dengan kinerja IKM. Dengan demikian, pengaruh teknologi sebagai variabel moderator pada pendemic Covid-19 tidak dominan, karena perusahaan IKM menghadapi penurunan permintaan dan memang mempengaruhi Sales Margin.

Kata Kunci: Internal Networking, Kinerja Usaha Industri Kecil dan Menengah, Teknologi

JEL Classification: M30, M31 


\section{Pendahuluan}

UKM (Usaha Kecil Menengah) merupakan tonggak dari ekonomi kerakyatan yang dapat menjadi penopang perekonomian masyarakat. UKM telah mampu menjadi penyumbang APBN di Indonesia. Peranan UKM dirasakan begitu penting karena sektor ini tidak hanya sebagai sumber mata pencarian, tetapi juga menyediakan lapangan kerja langsung maupun tidak langsung bagi masyarakat yang tingkat pengetahuannya dan keterampilannya yang relatif rendah.

Pandemi COVID-19 membawa dampak sangat besar di berbagai sektor, termasuk ekonomi. Wabah Covid-19 membuat sektor ekonomi dan dunia usaha di Indonesia begitu terpukul. Banyak pelaku usaha mikro, kecil, dan menengah (UMKM) kelimpungan menghadapi bisnisnya yang terhambat bahkan mungkin tidak bakal selamat. Secara global dampak Covid-19 telah merusak rantai pasokan, menjatuhkan harga komoditas, hingga meningkatnya risiko kehancuran ekonomi global. Secara domestik dampak Covid -19 telah mengurangi pengeluaran diskresioner, penutupan pabrik, hingga larangan berpergian. Meluasnya penyebaran virus corona atau Covid-19 mulai berdampak kepada lebih dari separuh koperasi dan Usaha Kecil dan Menengah di Sumatera Utara.

Industri kecil yang ada di Kota Medan pada umumnya masih merupakan kerajinan rumah tangga yang dikelola oleh para pengrajin secara tradisional dengan keterampilan yang diperoleh secara turun temurun dan masih menggunakan teknologi tradisional, sehingga mutu produk yang dihasilkan industri rendah dan desain produk terkesan monoton. Hal inilah yang menyebabkan daya saing produk yang dihasilkan industri rendah sehingga para pengrajin atau pengusaha kecil kurang termotivasi untuk mengembangkan usahannya dan pada akhirnya 58industri kecil yang dilakukannya Tetap sebagai usaha sampingan keluarga. Kurang berkembangnya industry kecil dan menengah di Kota Medan, disebabkan kurangnya informasi mengenai bahan baku, informasi kapasitas produksi, dan informasi pasar (pembeli) lokal, nasional, maupun internasional.

Dari sekian banyak sentra industri tersebut hanya sebagian kecil saja yang berprestasi dan sebagian besar kurang berkembang. Umumnya sentra industri yang berkembang pesat adalah sentra industri yang berada di Pulau Jawa, Bali, dan Nusa Tenggara. Sedangkan sentra industri (cluster) yang ada di Pulau Sumatera, khususnya Kotamadya Medan tidak menunjukkan prestasi ekspor yang signifikan (kurang berkembang). Keadaan ini tentunya tidak sesuai dengan keinginan/tujuan pemerintah dalam melaksanakan pendekatan cluster (sentra industri) usaha kecil dan menengah di Indonesia. Padahal, Pemerintah Kota Medan telah menganggarkan program pelatihan dan bantuan peralatan untuk mengembangkan produksi melalui Dinas Perindustrian dan Dinas Koperasi dan UKM (Tambunan, 1995).

Salah satu faktor yang paling penting dalam memaksimalkan kinerja UKM adalah pemasaran. Akan tetapi dalam masa pandemi Covid-19, pelaku UKM menghadapi kendala pemasaran yaitu penurunan permintaan secara drastis. Faktor lainnya adalah faktor produksi, dimana untuk bisa melakukan produksi, orang memerlukan tenaga manusia, sumber-sumber alam, modal dalam segala bentuknya, serta skill (Sumolang, Rotinsulu, \& Engka, 2019).

Bengkel las Jalan Makamah Medan terletak di lingkungan 7 Kelurahan Mesjid Kecamatan Medan Maimun Kota Medan merupakan cluster (sentra) Industri kecil dan Menengah (IKM) yang masih bertahan dalam persaingan bisnis. Bengkel las ini terdiri dari 103 bengkel las dan jumlah pekerja sebanyak 154 pekerja.. Bengkel las di Jalan Mahkamah Medan merupakan usaha yang dikelola secara perorangan yang menghasilkan berbagai produk seperti pagar pekarangan, pintu gerbang, jerjak pintu atau jendela rumah, aneka jenis permainan anak-anak yang terbuat dari besi dan lain-lain.

Berdasarkan observasi, pesanan yang dikerjakannya saat ini oleh pengusaha IKM sudah diorder jauhjauh hari sebelum virus corona mewabah. Namun dari segi bahan baku, semuanya sudah mengalami kenaikan. Kendala lain yang dihadapi IKM Medan adalah distribusi, hal ini karena para pelaku IKM Mahkamah belum memaksimalkan peran teknologi untuk mengatasi distribusi dan inefisiensi. Hal ini sesuai dengan pendapat Reswari, (2020) sebanyak 111 koperasi serta UMKM (setara 10 persen) mengungkapkan bahwa distribusi yang mereka lakukan menjadi terhambat, terlebih saat sudah ada penerapan PSBB di wilayah masing-masing.

Tambunan, (2005) mendefenisikan Cluster atau Sentra Industri sebagai suatu konsentrasi dari sekumpulan perusahaan-perusahaan kecil sejenis (dalam arti di bidang usaha atau sub sektor yang sama). Tambunan, (2017) sentra industri adalah perusahaan-perusahaan yang terkonsentrasi secara sektoral atau georafis. Selanjutnya, (Hill, 2001) mengatakan bahwa ada suatu trend yang jelas terhadap pengelompokan industri pada manufaktur di Indonesia. Mithsuhashi, (1999) menyatakan bahwa pengelompokan perusahaan juga memberikan suatu landasan untuk mendirikan pelembagaan industri yang mampu menyokong industri. Jaringan industri seperti ini, menyumbangkan suatu nilai tersendiri dan budaya dalam satu lokasi, dan penciptaan nilainilai ekonomi secara eksternal dan menciptakan adanya aksi bersama (join action), yang menghasilkan efisiensi 


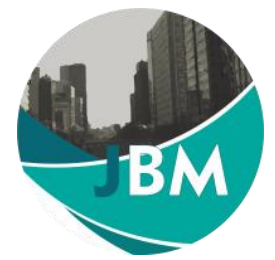

bersama dan menjadikan perusahaan-perusahaan yang berada di dalam cluster menjadi kompetitif, dalam beberapa kasus bahkan pada pasar internasional. Tambunan (1995) mengatakan bahwa manfaat sentra industri yaitu dapat menciptakan manfaat ekonomis bagi perusahaan-perusahaan yang mengelompok. Manfaat ini dapat terwujud bila sentra industri telah mempunyai jaringan internal (internal networks) dan jaringan eksternal (eksternal networks). Jaringan internal yang dapat terwujud adalah promosi, distribusi, produksi, persediaan bahan baku, dan pelatihan. Sedangkan jaringan eksternal (eksternal networks) adalah adanya hubungan kerjasama dengan perusahaan yang ada dalam cluster dengan perusahaan yang ada di luar sentra industri (cluster), seperti supplier, bank, universitas, perusahaan besar, dan sebagainya.

Sejak krisis moneter terjadi dampak yang dialami oleh sektor UKM, yaitu : tingginya suku bunga kredit, sehingga suplai kredit berkurang, berakibat kurang terbukanya sektor produksi, tingginya biaya impor bahan baku dan suku cadang, yang mengakibatkan meningkatnya biaya produksi, sehingga keperluan modal kerja meningkat, tingginya biaya untuk pemesinan, peralatan, dan suku cadang, yang berkaitan dengan teknologi, cash flow terganggu akibat lambatnya pembayar utang, nilai mata uang asing yang masih volatile, dan meningkatnya resiko transaksi antar negara (Soetrisno, 2002).

Menurut (Kotler, 2014) Promosi adalah cara mengkomunikasikan produk atau jasa yang dihasilkan perusahaan kepada konsumennya. Cara mengkomunikasikan dilakukan melalui iklan, promosi penjualan, hubungan masyarakat, penjualan pribadi, dan pemasaran langsung. Szymanski et al, 1993 meneliti pengaruh promosi terhadap market share, dimana hasil temuannya bahwa terdapat pengaruh yang signifikan antara promosi dengan market share perusahaan. (Buzzell \& Wiersema, 1981) meneliti 1200 perusahaan pada program PIMS menemukan promosi, personal selling, iklan dan promosi penjualan mempunyai hubungan yang kuat dengan market share.

Berdasarkan penelitian yang telah diakukan oleh Subroto, Hapsari, \& Astutie, (2016) yang berjudul Analisis Faktor-Faktor yang Mempengaruhi Kinerja Usaha Mikro Kecil dan Menengah (UMKM) Kabupaten Brebes, menyatakan bahwa pengaruh faktor produksi terhadap kinerja UMKM adalah positif dan signifikan faktor Produksi terhadap kinerja UMKM Kabupaten Brebes. Hasil penelitian Tirtayasa (2017) menemukan perubahan teknologi berpengaruh positif dan signifikan terhadap hubungan Strategi Masuk ke pasar dan kinerja pemasaran pada sektor manufacture. (Munizu, 2013) telah menemukan bahwa pengaruh teknologi ditemukan positif dan signifikan terhadap hubungan produksi dengan kinerja usaha IKM di Kota Medan. Jaworski \& Kohli, (1993), Narver \& Slater, (1990) dan Appiah-Adu, (1998) telah menemukan bahwa teknologi berpengaruh positif dan signifikan terhadap hubungan orientasi pasar dan kinerja usaha. Selain itu hasil penelitian Rianto \& Kurniawan, (2017) terdapat pengaruh positif signifikan saluran distribusi terhadap kinerja usaha. Penelitian (Tirtayasa, 2017) menemukan pengaruh positif dan signifikan antara distribusi dengan kinerja usaha IKM.

Hubungan orientasi kewirausahaan dengan Kinerja UKM tidak dipengaruhi oleh teknologi (Maltio \& Wardi, 2018). Hasil penelitian Jaworski \& Kohli, (1993), Narver \& Slater, (1990) dan Appiah-Adu, (1998) telah menemukan bahwa teknologi berpengaruh positif dan signifikan terhadap hubungan orientasi pasar dan kinerja usaha. Penelitian ini bertujuan untuk menganalisis pengaruh internal networking perusahaan terhadap kinerja yang dimoderasi oleh teknologi

\section{Metode Penelitian}

Penelitian ini menggunakan pendekatan penelitian eksplanatori, yang bertujuan untuk menjelaskan hubungan sebab akibat antara variabel penelitian dan hipotesis pengujian (Nasution, et al., 2020). Populasi penelitian ini sebanyak 103 usaha bengkel las yang berada dalam kelompok.sentra Industri Kecil Dan Menengah di jl. Mahkamah, Medan.Teknik sampling yang digunakan pada penelitian ini adalah teknik sampling jenuh, yaitu teknik pengambilan sampel bila semua anggota populasi digunakan sebagai sampel. Dan yang menjadi sampel dalam penelitian ini adalah seluruh bengkel las yang berada di Jalan Mahkamah Medan yang berjumlah 103 unit bengkel. Teknik pengumpulan data yang dilakukan dalam penelitian ini adalah sebagai berikut:Dokumentasi, wawancara, dan penyebaran angket.Dalam penyebaran angket, 3 angket tidak dapat digunakan karena jawaban tidak lengkap, jadi hanya 100 responden yang digunakan dalam penelitian ini. Penelitian ini menggunakan analis multivariate, uji data : Untuk mengetahui data yang digunakan layak atau tidak digunakan uji Validatidas dan Reliabilitas. Hasil uji Uji Validitas dan Uji Reliabilitas, dihasilkan seluruh items pernyataan dinyatakan layak (Valid dan Reliabel). Untuk menguji pengaruh teknologi (moderator variabel) terhadap hubungan jaringan internal 
(produksi dan distribusi) dengan kinerja usaha IKM, peneliti menggunakan Hierarchical Regression Analysis (HRA).

\section{Hasil Penelitian}

\section{Analisis Deskriptif}

Berdasarkan hasil survey, responden dengan jenis kelamin responden pria lebih banyak dari wanita yaitu pria 73 IKM (73\%). Selanjutnya, pengusahan IKM mengeluarkan modal awalnya sebesar Rp. 5.000.000 - Rp. 10.000 .000 sebesar $36 \%$. Jika dilihat dari perbandingan jumlah tenaga kerja sebelum dan pada masa covid-19, jumlah tenaga kerja yang sebelumnya 2-3 orang hanya pada 46 IKM (46\%), sementara itu pada masa covid jumlah tenaga kerja 2-3 orang meningkat menjadi 80 IKM. Selanjutnya, usaha yang memiliki tenaga kerja 3-4 orang sebelum covid berjumlah 30 IKM (30\%) menurun menjadi 8 IKM (8\%). Ini mengambarkan pengusaha IKM melakukan pengurangan jumlah tenaga kerja dikarenakan pesanan pekerjaan berkurang sebagai dampakk Covid-19. Dilihat dari aspek penjualan, hampir seluruh pengusaha IKM mengalami penurunan tingkat penjualan, umumnya penurunan penjualan terjadi menjadi lebih kecil yaitu Rp. 5.000.000-Rp.10.000.000 yang berjumlah 82 IKM (82\%). Biasanya sebelum covid tingkat penjualan dari Rp.10.000.000 sampai dengan Rp. 30.000.000. Tabel di bawah berikut merupakan perbandingan antara sebelum dan saat pandemi Covid-19.

Tabel 1 Analisis Deskriptif Usaha IKM Sebelum Pandemi Covid-19

\begin{tabular}{lcc}
\hline \multicolumn{1}{c}{ Uraian } & Frekuensi & Presentase \\
\hline Modal Awal & & \\
$\mathbf{5} .000 .000-10.000 .000$ & 36 & $36 \%$ \\
$10.000 .000-15.000 .000$ & 15 & $15 \%$ \\
$15.000 .000-20.000 .000$ & 12 & $12 \%$ \\
$20.000 .000-30.000 .000$ & 16 & $16 \%$ \\
$>$ >30.000.000 & 21 & $21 \%$ \\
\hline Jumlah tenaga kerja sebelum covid-19 & & \\
2 sampai 3 orang & 46 & $46 \%$ \\
3 sampai 4 orang & 30 & $30 \%$ \\
4 sampai 5 orang & 18 & $18 \%$ \\
5 sampai 6 orang & 3 & $3 \%$ \\
Lebih dari 6 orang & 3 & $3 \%$ \\
\hline Jumlah penjualan sebelum covid-19 & & \\
\hline 5.000.000 - 10.000.000 & 53 & $53 \%$ \\
10.000.000 - 15.000.000 & 14 & $14 \%$ \\
15.000.000 - 20.000.000 & 16 & $16 \%$ \\
20.000.000 - 30.000.000 & 10 & $10 \%$ \\
$>$ > 30.000.000 & 7 & $7 \%$ \\
\hline
\end{tabular}

Sumber : Pengolahan data survey (2020)

Tabel 2 Analisis Deskriptif Usaha IKM Saat Covid-19

\begin{tabular}{ccc}
\hline \multicolumn{1}{c}{ Uraian } & Frekuensi & Presentase \\
\hline Jumlah tenaga kerja selama covid-19 & & \\
2 sampai 3 orang & 80 & $80 \%$ \\
3 sampai 4 orang & 8 & $8 \%$ \\
4 sampai 5 orang & 10 & $11 \%$ \\
5 sampai 6 orang & 2 & $2 \%$ \\
Lebih dari 6 orang & - & - \\
Jumlah penjualan pada saat covid-19 & & $82 \%$ \\
5.000.000 - 10.000.000 & 82 & $11 \%$ \\
$10.000 .000-15.000 .000$ & 11 & $3 \%$ \\
$15.000 .000-20.000 .000$ & 3 & $1 \%$ \\
$20.000 .000-30.000 .000$ & 1 & $3 \%$ \\
\hline 30.000 .000 & 3 & \\
\hline
\end{tabular}

Sumber : Pengolahan data survey (2020) 
Jurnal Bisnis dan Manajemen

http://jurnal.unmer.ac.id/index.php/jbm/index
Volume 8 No 1

2021

HIm. 57 - 63

\section{Uji Hipotesis}

Berikut ini disajikan hasil pengujian hipotesis yang diajukan di dalam penelitian ini.

\section{Tabel 3. Pengujian Hipotesis}

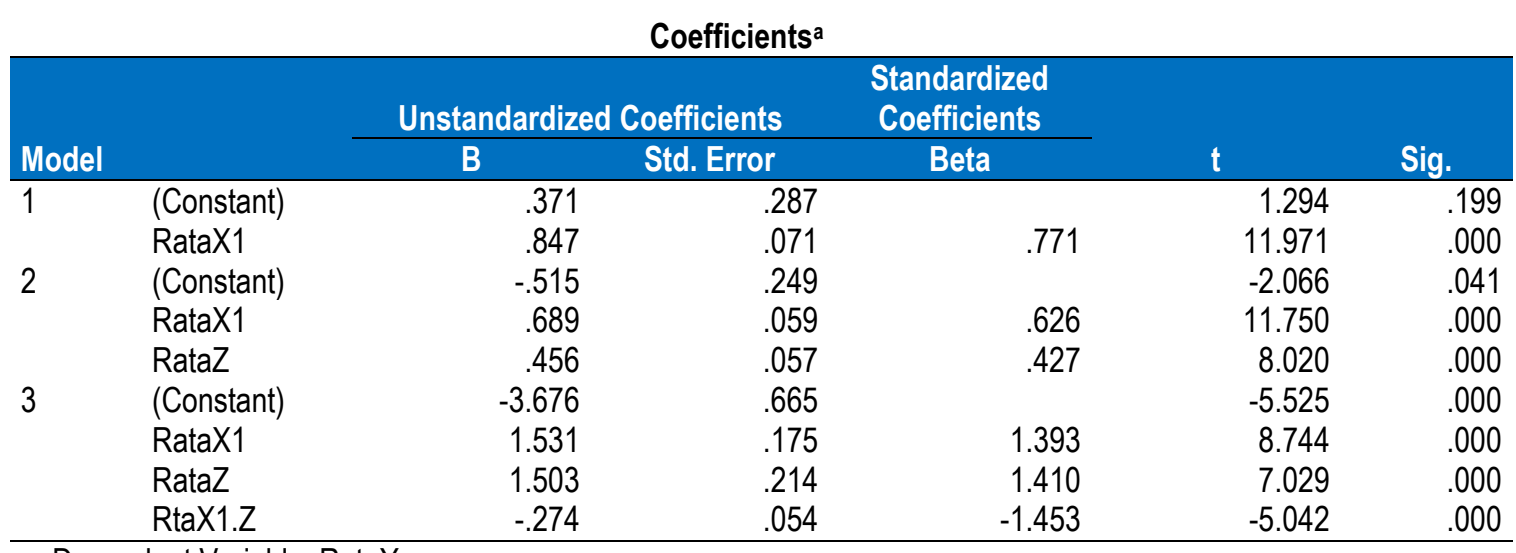

a. Dependent Variable: RataY

Sumber : Pengolahan data survey (2020)

Dari tabel di atas, untuk menguji $\mathrm{H} 1$ (model regresi 1) didapati bahwa sebesar 11.971 atau t.signifikan sebesar $0.000>=0.05$, ini berarti terdapat pengaruh positif dan signifikan antara produksi dan kinerja Usaha (H1 diterima). Sementara itu, untuk menguji hipotesis 2, peran teknologi sebagai moderator (model regresi 2) dapat dilihat dari nilai nilai $R^{2}$ naik dari 0.594 menjadi 0.756 , selanjutnya ketika teknologi berinteraksi (model regresi 3 ) $\mathrm{R}^{2}$ naik menjadi 0.807 . Selanjutnya, untuk melihat interaksi (pengaruh teknologi) terhadap hubungan produksi dengan kinerja usaha dapat dilihat bahwa uji-t sebesar -5.042 atau $0.000>=0.05$. Berdasarkan uji ini dapat disimpulkan bahwa pengaruh teknologi sebagai variabel moderator adalah negatif dan signifikan terhadap pengaruh produksi dan kinerja usaha IKM (H2 ditolak). Hasil uji H3 (model regresi1) di dapati bahwa sebesar 11.383 atau t.signifikan sebesar $0.000>=0.05$, ini berarti terdapat pengaruh positif dan signifikan antara distribusi dengan kinerja Usaha ( $\mathrm{H} 3$ diterima). Sementara itu, untuk menguji hipotesis 2, peran teknologi sebagai moderator (model regresi 2) dapat dilihat dari nilai nilai $\mathrm{R}^{2}$ naik dari 0.569 menjadi 0.578 , selanjutnya ketika teknologi berinteraksi (model regresi3) $\mathrm{R}^{2}$ naik menjadi 0.623 . Selanjutnya, untuk melihat interaksi (pengaruh teknologi) terhadap hubungan produksi dengan kinerja usaha dapat dilihat bahwa uji-t sebesar -0.366 atau 0.001 $>=0.05$. Berdasarkan uji ini dapat disimpulkan bahwa pengaruh teknologi sebagai variabel moderator adalah negatif dan signifikan terhadap pengaruh distribusi dan kinerja usaha IKM (H4 ditolak). Untuk lebih jelasnya lihat lampiran.

Tabel 4. Koefisien Determinasi (R-Square)

\begin{tabular}{lrrrr}
\hline \multicolumn{4}{c}{ Model Summary } \\
Model & R & R Square & Adjusted R Square & $\begin{array}{c}\text { Std. Error of the } \\
\text { Estimate }\end{array}$ \\
\hline 1 & $.771^{\mathrm{a}}$ & .594 & .590 & .49575 \\
2 & $.869^{\mathrm{b}}$ & .756 & .751 & .38640 \\
3 & $.898^{\mathrm{c}}$ & .807 & .801 & .34537 \\
\hline a. Predictors: (Constant), RataX1 & & \\
b. Predictors: (Constant), RataX1, RataZ & & \\
C. Predictors: (Constant), RataX1, RataZ, RtaX1.Z & \\
d. Dependent Variable: RataY & & \\
\hline
\end{tabular}

Sumber : Pengolahan data survey (2020)

\section{Pembahasan}

Hasil analisis pertama membuktikan bahwa terdapat pengaruh positif dan signifikan antara produksi dan kinerja usaha. Temuan penelitian ini sesuai dengan (Subroto et al., 2016) dan (Widjajanti, Sugiyanto, \& Marka, 2017) yang mendapati bahwa terdapat . pengaruh positifdan signifikan faktor Produksi terhadap kinerja UMKM.

Kedua, dari hasil hierarchy regression di dapati bahwa teknologi negative signifikan mempengaruhi hubungan produksi dengan kinerja usaha IKM. Artinya semakin banyak penggunaan teknologi maka membuat hubungan produksi dengan kinerja usaha IKM semakin rendah. Temuan ini bertentangan/tidak didukung oleh 
hasil penelitian Jaworski \& Kohli, (1993), Narver \& Slater, (1990) dan Appiah-Adu, (1998). Penolakan H2 bisa terjadi dikarenakan pada saat pendemi covid-19 pengusaha mengurangi produksinya dikarenakan berkurangnya pesanan/order, ini dapat dilihat dari hasil analisis desriptif pada table 1 bahwa pengusaha IKM mengalami penurunan tingkat penjualan, umumnya penurunan penjualan terjadi menjadi lebih kecil yaitu Rp. 5.000.000Rp.10.000.000 yang berjumlah 82 IKM (82\%). Dengan adanya penurunan penjualan, pengusaha lebih memaksimalkan penggunaan tenaga kerjanya untuk memproduksi dikarenakan pesanan/order yang berkurang. Bila order/pesanan meningkat pengusaha akan menambah kapasitas produksi dengan menggunakan mesin yang berteknologi tinggi.

Ketiga, hasil uji $\mathrm{H} 3$ di dapati bahwa terdapat pengaruh positif dan signifikan antara distribusi dan kinerja usaha IKM. Temuan penelitian ini sesuai dengan Rianto \& Kurniawan, (2017) dan Tirtayasa, (2017), dimana hasil penelitian terdapat $t$ pengaruh positif signifikan saluran distribusi terhadap kinerja usaha. Keempat, dari hasil uji $\mathrm{H} 4$ di dapati bahwa teknologi negatif signifikan mempengaruhi hubungan pdistribusi dengan kinerja usaha IKM. Artinya semakin banyak penggunaan teknologi maka membuat hubungan distribusi dengan kinerja usaha IKM semakin rendah. Temuan ini bertentangan/tidak didukung oleh hasil penelitian Jaworski \& Kohli, (1993), Narver \& Slater, (1990) dan Appiah-Adu, (1998). Berdasarkan analisis deskriptif (pada table 1) terjadi penurunan penjualan pada saat pendemi covd-19, dimana penurunan penjualan terjadi menjadi lebih kecil yaitu Rp. 5.000.000-Rp.10.000.000 yang berjumlah 82 IKM (82\%). Dengan penurunan permintaan dari konsumen secara tidak langsung berdampak langsung mengurangi biaya distribusi dan akhirnya berdampak terhadap kinerja usaha IKM. Pengunaan teknologi dalam bentuk E-commerce tidak berdampak langsung dikarenakan konsumen yang memesan produk hanya pada daerah sekitar Kota Medan saja. Hal yang berbeda terjadi pada saat normal (tidak pendemi) dimana konsumen banyak berasal dari luar Kota Medan.

\section{Kesimpulan}

Hasil penelitian menunjukkan bahwa produksi dan distribusi berpengaruh positif dan signifikan terhadap kinerja IKM. Pengaruh teknologi sebagai pengaruh moderator ditemukan pengaruh negatif dan signifikan hubungan produksi dan distribusi dengan kinerja IKM. Dengan demikian, pengaruh teknologi sebagai variabel moderator pada pendemic Covid-19 tidak dominan, karena perusahaan IKM menghadapi penurunan permintaan dan memang mempengaruhi Sales Margin. Implikasi dalam penelitian ini adalah sebagai berikut: Dampak pendemik covid-19 pada Industri Kecil dan Menengah (IKM) sangat terasa ini dapat dilihat sebagian besar pengusaha mengalami pengurangan penjualan dan melakukan pengurangan pekerja. Bila pendemik covid-19 ini terjadi dalam waktu yang lama, maka akan mengakibatkan kebangkrutan pengusaha IKM sebagai akibat turunnya permintaan dari konsumen. Oleh karena itu, pemerintah sebaiknya memberikan stimulus berupa bantuan keringanan pembayaran kredit pinjaman bank dan melakukan pelatihan pengelolaan usaha yang efisien dan berdaya saing tinggi. Pemerintah juga dapat membantu pelaku usaha IKM dengan menggunakan pemasaran bersama dengan melibatkan usaha IKM ini dengan System Informasi Marketing di dinas Perindustrian atau bekerjasama dengan portal e-commerce seperti Bukalapak, dan lain-lain.

\section{Daftar Pustaka}

Appiah-Adu, K. (1998). Market Orientation and Performance: Do the Findings Established in Large Firms Hold in the Small Business Sector? Journal of Euromarketing, 6(3), 1-26.

Buzzell, R. D., \& Wiersema, F. D. (1981). Successful Share-Building Strategies. Harvard Business Review, 342357.

Hill, H. (2001). Small and medium enterprises in Indonesia: Old policy challenges for a new administration. Asian Survey, 41(2), 248-270.

Jaworski, B. J., \& Kohli, A. K. (1993). Market Orientation: Antecedents and Consequences. Journal of Marketing, 57(3), 53-70.

Kotler, P. (2014). Manajemen Pemasaran, Analisis, Perencanaan dan Pengendalian. (J. Wasana, Ed.) (Edisi mile.). Jakarta: Erlangga.

Maltio, M., \& Wardi, Y. (2018). The Influence of Marketing Mix, Islamic Tourism and satisfaction on Visitor Loyalty: a Literature Review. 2nd Padang International Conference on Education, Economics, Business and Accounting (PICEEBA-2 2018) (pp. 402-410).

Mithsuhashi, K. (1999). A Chalenger for Small and Medium Enterprises in Japan: Recognization of Industrial Clustering. International Converence (p. 7).

Munizu, M. (2013). Strategi Peningkatan Kinerja Dan Peran Usaha Kecil dan Menengah (UKM) Pengolah Produk Berbasis Pangan. Jurnal Manajemen \& Bisnis, 12(1), 101-110. 
Narver, J. C., \& Slater, S. F. (1990). The Effect of a Market orientation on Business Profitability. Journal of Marketing, 54(4), 20-35.

Nasution, M. I., Fahmi, M., Jufrizen, J., Muslih, M., \& Prayogi, M. A. (2020). The Quality of Small and Medium Enterprises Performance Using the Structural Equation Model-Part Least Square (SEM-PLS). Journal of Physics: Conference Series, 1477(2020), 1-7.

Reswari, D. M. I. (2020). Pandemi Corona, Ini 5 Keluhan Para Pelaku Bisnis UMKM. Retrieved from https://www.jurnal.id/id/blog/keluhan-para-pelaku-bisnis-umkm-saat-corona/

Rianto, S., \& Kurniawan. (2017). Pengaruh Kemitraan dan Kewirausahaan Terhadap Saluran Distribusi, serta Pengaruhnya Terhadap Kinerja UMKM di Kabupaten Purbalingga. JBIMA (Jurnal Bisnis dan Manajemen), 5(2), 170-183.

Soetrisno, N. (2002). Strategy for Strengthening SMEs Through Business Cluster Approach (Concept, Empirical Experience, and Hope. Jakarta.

Subroto, S., Hapsari, I. M., \& Astutie, Y. P. (2016). Analisis Faktor-Faktor yang Mempengaruhi Kinerja Usaha Mikro Kecil dan Menengah (UMKM) Kabupaten Brebes. Prosiding SNaPP: Sosial, Ekonomi dan Humaniora (pp. 337-344).

Sumolang, Z. V., Rotinsulu, T. O., \& Engka, D. S. M. (2019). Analisis Faktor-Faktor Yang Mempengaruhi Produksi Industri Kecil Olahan Ikan Di Kota Manado. Jurnal Pembangunan Ekonomi Dan Keuangan Daerah, 19(3), 1-17.

Tambunan, T. (1995). Cluster Diagnosis in Padang Rattan Industries and Proposed Action Plan. Jakarta.

Tambunan, T. (2005). Promoting small and medium enterprises with a clustering approach: A policy experience from Indonesia. Journal of Small Business Management, 43(2), 138-154.

Tambunan, T. T. H. (2017). Development of small-scale industries during the new order government in Indonesia. Development of Small-Scale Industries during the New Order Government in Indonesia. Aldershot, UK: Ashgate Publishing.

Tirtayasa, S. (2017). Marketing Strategies Influences On SMEs Cluster Performance. International Journal of Scientific \& Technology Research, 6(6), 187-191.

Widjajanti, K., Sugiyanto, E. K., \& Marka, M. M. (2017). Internal Strategic Resource Sebagai Upaya Meningkatkan Kinerja Penjualan Usaha Mikro Kecil Menengah Di Kabupaten Kudus. Jurnal Dinamika Sosial Budaya, 18(2), 241-250. 